\title{
Myth, Family Disputes and His Talent's Influence on Alexander the Great's life
}

\author{
Jingxuan Du \\ Nanjing Foreign Language School, Nanjing, Jiangsu, 210008, China \\ dongqingslime@foxmail.com

\begin{abstract}
Alexander the Great is one of the most legendary figures in ancient Greek and Roman history. It's amazing how he was born, how he grew up, how talented he was, and what he achieved. Alexander the Great came from mythology, and he lived with Greek mythology all his life. He learned from the myth what it takes to be a leader, a warrior. Family disputes ran through almost the entire first half of his life, and he was on his way to becoming a great emperor. It was his talent that allowed him to lead his troops to victory in a war where he was outnumbered and built a vast empire. Throughout his life, myths, family disputes and personal talent were all part of his success.
\end{abstract}

Keywords: Alexander the Great, myth, family disputes

\section{MYTHOLOGY, EDUCATION AND FAMILY'S CONCEPT}

\subsection{Legendary origin}

Do you think that, his family played a important role in Alexander the Great's success? If his family had not been so, whether he would have become the military prodigy that dominated the battlefield? If his family had not been so, whether he would have had such a brilliant but short life? If his father was not the leader of Macedon and his mother was not a princess of the royal house of Molossia in Epirus, whether he would have had the ability to turn Macedonia from a small border country into a vast empire?

Olympias, Alexander's mother, was supposed to be the son of Neoptolemus and Andromache. Neoptolemus once killed King Priam at the altar of Zeus Herkeios, so Alexander was the descendant of a flawed hero, who sacrilege Zeus. However, Alexander thought that his blood from ancient heroes was not his identification with history of the past. Also, Olympias delivered her belief in the connection between gods and him and his destiny to Alexander, which made Alexander the Great believed that he had the blood of heroes and he was a part of the Greece epics. [1] Alexander did not want the deeds of his "ancestors" to control his life. He wanted to be legendary. In a sense, Alexander did not blindly identify with the past or with the divine.
On the other hand, Alexander's unique destiny had been predicted in his parent's dreams before he was born. Olympias dreamed that a thunder hit her womb, then the flame spread far away before it died. [2] Also, Phillip II, who was the father of Alexander, dreamed that he tried to seal his wife's womb, and there was a lion on the seal. [3] When Alexander was born on 20 July 356, his father received three excellent message, which meant that Alexander would be unbeatable and invincible. [4] Those coincidental incidents seemed to have a big influence on Alexander's life. This vision will be of no small benefit to his future development -- in the first place, he will be brought up as a child of great talent. Second, as the descendant of a hero, his position in the family is naturally guaranteed(but sadly, this did not seem to be the case later).

Surprisingly, Alexander did have military and leadership talents. $\mathrm{He}$ was willing to chat with ambassadors from Persian about their journey from Persia, their king, the experiences of wars and so on, which were proved to be very important to his future. [5] Alexander himself was a man of power and ambition. The Thessalians presented Philip II with a wild horse called Bucephalas, but Philip's groom could not tame the horse, which would not let anyone near him. [6] Alexander stepped forward and offered to try and tame the wild horse. If he did not succeed, he would offer the price of the horse. He found that the horse was afraid of his own shadow, and he took advantage of this and succeeded in taming him. Philip II was very pleased and said that 
Macedon was too small for his ambitions and that he needed a larger empire. [7] After that, Leonidas, a relative of Olympias, began to teach Alexander how to tame the Bucephalas. [8]

\subsection{Aristotle's teachings and self-awareness}

Because of the blood of hero in Alexander, he received excellent education. Leonidas was a very strict man. On one occasion Alexander tried to throw incense on the altar-fire with his hands while making sacrifices to the gods, but Leonidas stopped him. [9] This also shows that Alexander was a man of great reverence for the gods, and this never changed during his life. [10] Later, Alexander sent him a letter with a lot of money. Alexander explained in the letter that he was sending him so much money that he would not be too stingy with the gods in the future.

When Alexander was fourteen, Philip II invited Aristotle to be his teacher. Aristotle was a famous philosopher of his time, and he taught Alexander ethics, politics, and eristics. Aristotle also gave Alexander a copy of Homer's Iliad. He carried the book with him during the eastern expeditions and the book is one of the few things he treasured. [11] The book's influence on him was enormous, and it provided Alexander with a series of ways to wage a war of revenge against Asia. During a visit to Troy in $334 \mathrm{BCE}$, Alexander offered sacrifices to Achilles and other Greek heroes. [12] Alexander greatly appreciated Achilles' acceptance of his own death, in which he could gain glory. This appreciation also set the course of Alexander's life. He was willing to give his life for anything he wanted, which was a great advantage in battle. [13] From this, we can see that Greek mythology had a great influence on Alexander, from which he learned to be fearless and brave, which may be the reason why he was invincible.

Aristotle had advised Alexander to treat the people of the conquered regions as plants and animals, following his belief in the obedience of nature. But Alexander did not, preferring to treat some of them as human beings. In a sense, Alexander's teachers and family merely created a step for him. Behind the steps, the road to the legend was built by Alexander himself. His reverence for the gods, his self-understanding of myth, his strategy for war, his courage and ambition, all lay the foundation for his success.

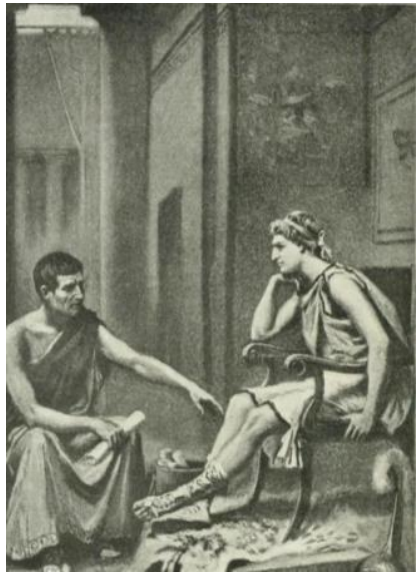

Figure 1 Alexander the Great and Aristotle

\section{FAMILY DISPUTES}

\subsection{A new queen and a pure-blood heir}

But Alexander's path to legend was never going to be smooth. In 337 BCE, Philip II married his eighth wife, Cleopatra, the niece of Attalus. [14] The marriage would undoubtedly bring Philip II a new heir. At the wedding feast, Attalus drank too much and prayed to the gods that Philip II and his niece Cleopatra would have a legitimate heir to the throne. Alexander's mother Olympias was not Macedonian, she was the princess of Morosia, so Alexander was only half Macedonian. Alexander thought attalus was insulting him for being a bastard, so he threw his cup over attalus' head. [15] Philip was so angry at this that he drew his sword and tried to run Alexander through it. But he fell because he drank too much. [16] After this, Olympias accused Philip of wanting to murder her son, so Philip divorced Olympias, accusing her of adultery, and Alexander left Macedonia for Illyria. Philip II may have acted out of passion, but it was the beginning of many problems between Alexander and his father. After this, the discord within the Macedonian royal family also reached a climax. After this, Alexander seems to have lost the trust of Philip II, and his position in Macedonia has plummeted.

In order to strengthen his alliance with the Persian governor and for the future conquest of Asia, he decided to let Alexander's half-son Philip Arrhidaeus marry the governor's eldest daughter. However, Alexander's friends and Olympias felt that Philip II intended his mentally impaired brother to succeed him, so Alexander sent his good friend to replace Philip Arrhidaeus as the husband of the governor's daughter. However, when Philip found out, he accused Alexander of being ignoble and exiled his best friends. [17] The fact that Alexander was an impure Macedonian would be controversial, of course. But all Philip seemed to do was to give Alexander a sense of isolation. If Philip II had not been assassinated, it is doubtful whether Alexander would have been the heir of Macedon. 
In 336, Philip II sent an expedition led by Attalus to recover the Greek cities in Asia Minor. He asked Pythia to prophesy for him whether he could conquer the Persian king. The ambiguous prophecies of the time convinced him that the Persian king would be killed in battle. So, on the very eve of the expedition, he arranged the wedding of his daughter Cleopatra to Alexander of Epirus. [18] The wedding reception was like a turning of the ages, heralding the death of Philip II, the great reshuffle of the royal family and the beginning of Alexander's glorious story.

\subsection{The bloodbath that began with the death of Philip II}

When Philip II went to the wedding of his daughter to King Epirus (brother of Olympias), a man rushed out and killed Philip II with a knife in his hand. The assassination has been linked by some to Olympias and Alexander. In any case, Alexander benefited greatly from his father's death -- in a sense, his chances of succeeding to the throne came from his father's death. After this, those who wanted a man of full Macedonian descent to the throne were effectively eliminated, and Alexander was able to return to the center of contention for the throne once more. Later, in a letter Alexander wrote to Darius III, he also accused Philip II of a murder for hire by Darius III, which became an important reason for his invasion of Persia. [19]

Justin and Plutarch, however, believed that the murder of Philip II was a conspiracy between Olympias and Alexander. Olympias had encouraged Pausanias to take revenge on Philip II, had encouraged her brother, Alexander of Epirus, to go to war, and she had prepared horses for the assassins. After Philip II died, she personally killed Cleopatra's daughter and forced Cleopatra to hang herself. Most importantly, the dagger that stabbed the king was named Myrtales (Olympias's original name), as if to tell the world that she had done it. [20] Unfortunately, that's just Justin's claim. It was understandable that Philip II's death would have brought joy to Olympias, but it was not an indictment of her. In any event, Alexander reclaimed his place from the affair.

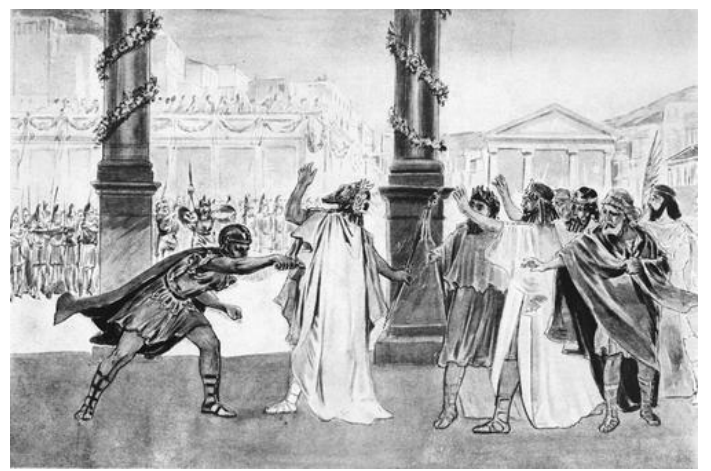

Figure 2 the death of Philip II
In addition to the deaths of Cleopatra and her daughter, Alexander also caused a lot of blood for the throne. Attalus is assassinated and Armintas (the rightful heir to the throne) suddenly disappears. After this, Alexander became the only descendant and was fully capable of leading Macedonia against the Persians. Alexander recalled his best friends, who had been exiled by Philip II. Upon their return to Macedonia, these men were quickly promoted to some of the highest positions in the army or in the administrative units of Alexander's empire. The involvement of these "barbarians" also put Alexander even more at odds with the heir attalus had in mind. During Alexander's lifetime, family rivalries pushed him almost out of sight of Philip II, but also propelled him directly to the throne.

\section{A JOURNEY OF CONQUEST TO SHOWCASE HIMSELF'S TALENTS}

After Alexander was made king of Macedon, he gained the Thessalians', the Amphictyons', and the Ambraciots' approval by reminding and fawning over the ancient kinship. The Athenians also sent envoys in a tense atmosphere to ask his forgiveness (for failing to confirm his leadership in time). [21] After that, he also persuaded the Greeks to join them. At this point, he successfully took over his father's revenge campaign.

After the alliance was agreed, there was a rebellion in Thebes, where Alexander was falsely claimed to have died. Alexander surrounded Thebes, but made no move. He demanded the rebels surrender and promised to forgive them. The Theban, however, made very rash demands. Before Alexander could give the order, Podicus rushed into Thebes. Only a few of them (mostly priests, priestesses, and rebels) survived; the rest were killed or enslaved. It was a high-minded, culturally selective conquest. This in fact partly reflected Alexander's view of the people of the government -- he preferred to see them as equal beings rather than as objects driven by others.

Interestingly, during the conquest of Thebes, Timokleia was raped by a Thracian leader. She pushed the Thracian rapist into a well and killed him. When asked to be executed, she said that her brother Theagenes had died at the hands of Philip II for the freedom of Greece. Surprisingly, Alexander did not kill her, but admired it. [22]

Alexander also had a very interesting habit of making great sacrifices and holding celebratory games both before and after great events, which was a good sign of his reverence for the gods. Throughout his life, he had an unwavering admiration for the gods. This may have something to do with the education he received from his mother, including his legendary birth experience. His belief in the gods was reflected in the panhellenic Army's crusade in the east. He offered sacrifices to Poseidon at 
sea, performed many ceremonies on his way from Europe to Asia, and offered sacrifices to Priam at Troy. Claiming to be the son of Zeus, he landed in Asia with a spear thrust into the ground as a symbol of the god-given land. Here we can see that Alexander took some of the values of the mythological hero and acted accordingly.

Alexander's epic battle of the East begins at the battle of Granicus. The victory, in my view, was threefold. First, Alexander's army was well trained. Second, Alexander was a gifted general. Third, Alexander and his army had a heroic spirit. In the battle, despite the tiredness of the long journey, they forced their way across the river to fight and won the victory when the enemy was outnumbered. This battle also enabled Alexander to gallop across Asia Minor. In the battle of Issus, The battle of Tyre and other battles, Alexander and his army also remained courageous attitude and good command. That's how he ended up building such a huge empire. When Alexander conquered Persia, he also made a decision to "Orient". He married a Sogdian woman, Roxana, and changed his cruel style of treating prisoners of war in the region. He also recruited local people into the army, following the local system. In addition, Alexander adopted eastern etiquette, wearing a Persian crown and a crimson robe, and requiring his subjects to bow to him and kneel. This caused discontent among the generals and soldiers, and it grew into opposition to Alexander. In this conflict, many opponents, including some of the most distinguished veterans of the war, were killed by Alexander, also caused a great rift in the expeditionary army.

After this, Alexander continued to pursue his ambitions in India. By this time, however, the disaffection of the army was so great (due to weather and plague) that Alexander chose to withdraw from India. In the campaign, Alexander also changed the idea that only The Greeks were civilized people.

\section{CONCLUSION}

We can conclude that Alexander the Great owes his success to many factors. His legendary birth, his reverence for Greek mythological figures, gave him an unusual starting point. And his family disputes, which seemingly made his path to the throne more difficult, actually accelerated his ascent to the throne. Of course, his own military genius and innate ambition were part of his empire. In this study, we discuss in depth three important factors of Alexander's success and explain the reasons for his unprecedented success, which is very helpful for us to have a deep understanding of the history of Greece and Rome. In our next exploration, we will look at other factors that contributed to Alexander's success, such as his close friends and teachers.

\section{REFERENCES}

[1] Castro-Torres Y, Katholi R E , Khan N Y . Aspirin for Primary Prevention of Cardiovascular Diseases: Current Concepts, Unanswered Questions and Future Directions[J]. Hellenic journal of cardiology : HJC = Hellēnikē kardiologikē epitheōrēsē, 2015, 56(6):461.

[2] Bosman P . Signs and Narrative Design in Plutarch's Alexander[J]. Akroterion, 2011, 56.

[3] Bosman P . Signs and Narrative Design in Plutarch's Alexander[J]. Akroterion, 2011, 56.

[4] A. J. Gossage. Plutarch's Life of Alexander J. R. Hamilton: Plutarch, Alexander. A Commentary. Pp. lxix +231 . Oxford: Clarendon Press, 1969. Cloth, $£ 2.75$ net.[J]. The Classical Review, 1971.

[5] Nijolè Juchnevičienè. Plutarch's Alexander: Problems of Interpretation[J]. Literature, 2010(3):10.

[6] Gossage, A. J. Plutarch's Life of Alexander J. R. Hamilton: Plutarch, Alexander. A Commentary. Pp. 1xix+231. Oxford: Clarendon Press, 1969. Cloth, 2.75 net[J]. Classical Review:new, 1971, 21(01):3739.

[7] Pelling C . Plutarch. Life of Alexander. Trans. K. J. Maidment. Auckland, N.Z.: The University Press. 1971. Pp.80. 85 cents N.Z[J]. The Journal of Hellenic Studies, 1973, 93:231-232.

[8] Melville S C . An Echo of Assyria in Plutarch's Life of Alexander[M]. 2019.

[9] Plutarch, Dryden J . "Alexander by Plutarch"[J]. Massachusetts Institute of Technology:the Internet Classics Archive, 2009.

[10] Rogers G M . Alexander : the ambiguity of greatness[M]. Random House, 2005.

[11] Narusawa K . Campaspe and Plutarch's Life of Alexander[J]. Treatises \& Studies, 1981, 7.

[12] Gossage, A. J. Plutarch's Life of Alexander J. R. Hamilton: Plutarch, Alexander. A Commentary. Pp. lxix+231. Oxford: Clarendon Press, 1969. Cloth, 2.75 net[J]. Classical Review:new, 1971, 21(01):3739.

[13] Doukas C , Stavropoulos P, Papacharalampopoulos A, et al. On the Estimation of Tool-wear for Milling Operations based on Multi- Sensorial Data $i\{[\mathrm{~J}]$. Procedia CIRP, 2013, 8(1):415-420.

[14] Hammond N . Part 1 || Diodorusl" Narrative of the Sacred War and the Chronological Problems of 357352 B. C[J]. Journal of Hellenic Studies, 1937, 57:44-78. 
[15] Hammond N. Part 1 || Diodorus\" Narrative of the Sacred War and the Chronological Problems of 357352 B. C[J]. Journal of Hellenic Studies, 1937, 57:44-78.

[16] Melville S C. An Echo of Assyria in Plutarch's Life of Alexander[M]. 2019.

[17] Vickers M. A SOURCE IN PLUTARCH'S LIFE OF PELOPIDAS FOR LADY MACBETH[J]. Notes \& Queries, 1986, 33(3):365-367.

[18] Diodorus.Bibliotheke or Library Book 16 Chapters 91-95; Book 17.1-16.16.91.2.

[19] Fears J R. Arrian/AnabasisAlexandri (Book Review)[J]. American Historical Review, 1977.

[20] Justin.Book 11 Chapters 1-4 (Background and Alexander' s accession).9.7.1-14.

[21] Diodorus.Bibliotheke or Library Book 16 Chapters 91-95; Book 17.1-16 .17.4.6.

[22] Nijolè Juchnevičienè. Plutarch's Alexander: Problems of Interpretation $[\mathrm{J}]$. Literature, 2010(3):10. 